\title{
Efektivitas Krim Ekstrak Sarang Burung Walet Terhadap Penyembuhan Luka Mencit Di Kota Bima
}

\author{
Abdul Haris \\ Mahasiswa Program Studi Magister Administrasi Kesehatan Univ.Qamarul Huda Badaruddin Bagu
}

\begin{tabular}{l} 
Article Info \\
\hline Article history: \\
Received Jul 09 ${ }^{\text {th }}, 2019$ \\
Revised Aug 05 ${ }^{\text {th }}, 2019$ \\
Accepted Aug $12^{\text {th }}, 2019$ \\
\hline
\end{tabular}

Keyword:

Swiftlet Nest Cream

Wounds

Mice

\begin{abstract}
Wounds were common and can affect everyone in the world, from children to adults. Wounds were physical damage that occurs when a person's body was suddenly exposed to excessive force or the continuity of a tissue was cut off due to an injury or surgery. Children aged 5-15 years were quite susceptible to injury, at that age children have a high curiosity and have a desire to explore something and experiment that is not balanced with the ability to understand or react to danger. Primary school-age children who suffered injuries as much as $42.56 \%$ consisted of $36.89 \%$ minor injuries and $5.67 \%$ severe injuries. The most common types of injuries were scratched $31.2 \%$ and then injuries due to bruising, sprains, biting, tearing, burns, traffic accidents, small objects getting in, and $1.1 \%$ broken bones (Kuschithawati; 2007). This study aims to determine the effectiveness of swiftlet nest in the process of healing wounds of mice. The type of research method used was true experiment with Posttest Only Control Group Design research design with a sample of 15 mice divided into 3 groups. The analysis in this study was a bivariate analysis using one way ANOVA test. The results showed the duration of healing wounds of mice.
\end{abstract}

Copyright ( Jurnal Analis Medika Bio Sains All rights reserved.

\begin{abstract}
ABSTRAK
Luka merupakan hal yang sering terjadi dan dapat mengenai semua orang di seluruh dunia, mulai dari anakanak sampai orang dewasa. Luka merupakan kerusakan fisik yang terjadi ketika tubuh seseorang secara tibatiba terpajan kekuatan yang berlebihan atau terputusnya kontinuitas suatu jaringan oleh karena adanya cedera atau pembedahan. Anak-anak yang berusia 5-15 tahun cukup rentan mendapatkan cedera, pada usia itu anak mempunyai rasa ingin tahu yang tinggi dan mempunyai keinginan untuk menelusuri sesuatu serta bereksperimen yang tidak seimbang dengan kemampuan dalam memahami atau bereaksi terhadap bahaya. Anak-anak usia SD yang mengalami cedera sebanyak $42,56 \%$ terdiri dari cedera ringan 36,89\% dan cedera berat $5,67 \%$. Jenis cedera yang paling umum adalah tergores $31,2 \%$ kemudian cedera karena memar, terkilir, tergigit, robek, luka bakar, kecelakaan lalu lintas, kemasukan benda kecil, dan patah tulang 1,1\% (Kuschithawati; 2007). Penelitian ini bertujuan untuk mengetahui Efektivitas sarang burung walet dalam proses penyembuhan luka mencit. Jenis metode penelitian yang digunakan adalah true experiment dengan rancangan penelitian Posttest Only Control Group Design dengan jumlah sampel 15 ekor mencit yang dibagi menjadi 3 kelompok. Analisis dalam penelitian ini adalah analisa bivariate dengan menggunakan uji one way anova. Hasil penelitian menunjukan lama waktu penyembuhan luka mencit yaitu pada hari ke 5 pada kelompok intervensi dengan krim ekstrak sarang burung walet $20 \%$ dengan nilai p value $0,001 \quad(<0,05)$, kesimpulannya pemberian krim ekstrak sarang burung walet $20 \%$ lebih efektif dalam penyembuhan luka mencit dibandingkan dengan ekstrak sarang burung walet $10 \%$.
\end{abstract}


Copyright $\odot$ Jurnal Analis Medika Bio Sains

\begin{abstract}
Pendahuluan
Banyak cara yang telah dikembangkan untuk penyembuhan luka seperti menjahit luka, menggunakan antiseptik dosis tinggi, dan juga pembalutan dengan menggunakan bahan penyerap. Namun ketika diteliti lebih lanjut, ternyata cara penyembuhan seperti ini sama sekali tidak membantu bahkan beresiko memperburuk luka. Dalam kehidupan sehari-hari biasanya masyarakat akan menggunakan antiseptik pada luka dengan tujuan menjaga luka tersebut agar menjadi steril. Bahkan antiseptik seperti hydrogen peroxide, providone iodine, acetic acid, dan chlorohexadine selalu tersedia di kotak obat. Sekarang perlu diketahui, masalah utama yang timbul akibat antiseptik tersebut ternyata tidak hanya membunuh kuman-kuman yang ada, akan tetapi juga membunuh leukosit yaitu sel darah yang dapat membunuh bakteri pathogen dan jaringan fibroblas yang membentuk jaringan kulit baru.

Salah satu bahan dari alam yang ditemukan memiliki efek menyerupai growth factor adalah sarang burung walet. Dalam penelitian Kong et al sarang walet ditemukan memiliki potensi mitogenik, dan berhasil membuktikan adanya epidermal growth factor pada sarang walet yang menstimulasi sintesis DNA pada fibroblast. Penelitian Kyung (Kyung, 2012) ekstrak sarang burung walet dapat meningkatkan proliferasi dari stem cell yang diambil dari jaringan adiposa manusia. Efek mitogenik dari sarang burung walet diduga karena adanya sialic acid. Asam sialic mewakili keluarga molekul gula dengan struktur kimia yang unik dan sangat bervariasi dan sering ditemukan dalam posisi terminal rantai oligosakarida pada permukaan sel dan molekul yang memungkinkan mereka untuk berperan dalam beberapa fungsi biologis penting (Schauer dan Traving., 1998). Sarang burung walet juga kaya akan glycosaminoglycan yang mirip dengan extracellular matrix (Nakagawa., 2007). Tujuan penelitian ini inin mengetahui Efektivitas dari krim ekstrak sarang burung walet terhadap percepatan penyembuhan luka mencit.
\end{abstract}

\title{
Metode
}

Jenis penelitian yang digunakan adalah True Experiment yang mana rancangaan penelitian ini yaitu replikasi, randomisasi, dan kontrol yaitu untuk mengetahui kemungkinan adanya saling hubungan sebab akibat dengan cara mengenakan satu atau lebih kondisi perlakuan kepada satu atau lebih kelompok eksperimen dalam membandingkan hasilnya dengan kelompok kontrol yang dikenai perlakuan dan tidak dikenai kondisi perlakuan. (Notoatmodjo, 2012). Rancangan penelitian menggunakan eksperimental Posttest Only Control Group Design (Marczyk et al., 2005) karena populasi dianggap homogeny.

Teknik pengumpulan data menggunakan lembar observasi untuk menilai tingkat percepatan penyembuhan luka menggunakan penilaian makroskopis kriteria Nagaoka. Analisis data menggunakan analisis bivariate yang mengkaji antara kelompok kontrol dan kelompok intervensi, dengan menggunakan uji parametric dengan one way anova

\section{Metode Penelitian}

Bagian metode ditulis dengan memuat 15-20\% dari artikel memuat rancangan dan desain penelitian, teknik pengumpulan dan analisis data

\section{Hasil Penelitian dan Pembahasan}

Tabel 1 Gambaran Percepatan Penyembuhan Luka Mencit

\begin{tabular}{|c|c|c|c|c|c|c|c|c|c|c|c|}
\hline Kel. & $\begin{array}{l}\text { Jumlah } \\
\text { Mencit }\end{array}$ & \multicolumn{10}{|c|}{ Penyembuhan luka hari ke } \\
\hline \multirow[t]{4}{*}{$\mathbf{K}$} & 1 & • * & $\bullet *$ & • * & • * & - * & $\bullet+$ & $\bullet+$ & $\bullet+$ & + & + \\
\hline & 2 & • * & • * & • * & • * & - * & • * & $\bullet+$ & $\bullet+$ & + & $\sqrt{ }$ \\
\hline & 3 & • * & • * & • * & • * & • * & • * & • * & • * & $\bullet+$ & + \\
\hline & 5 & • * & $\bullet *$ & - * & • * & • * & $\bullet+$ & • * & $\bullet+$ & $\bullet+$ & $\bullet+$ \\
\hline \multirow[t]{2}{*}{ P I } & 1 & - * & •* & - * & $\bullet+$ & $\bullet+$ & + & $\sqrt{ }$ & & & \\
\hline & 2 & • * & • * & • * & • * & $\bullet+$ & + & + & $\sqrt{ }$ & & \\
\hline
\end{tabular}




\begin{tabular}{ccccccccc}
3 & $\bullet *$ & $\bullet *$ & $\bullet *$ & $\bullet *$ & $\bullet *$ & $\bullet+$ & + & $\sqrt{ }$ \\
4 & $\bullet *$ & $\bullet *$ & $\bullet *$ & $\bullet *$ & $\bullet+$ & + & $\sqrt{ }$ \\
& $\bullet *$ & $\bullet *$ & $\bullet *$ & $\bullet *$ & $\bullet+$ & $\bullet+$ & + \\
\hline P II & 1 & $\bullet *$ & $\bullet *$ & $\bullet *$ & $\bullet+$ & $\bullet+$ & + & $\sqrt{ }$ \\
& $\bullet$ & $\bullet *$ & $\bullet *$ & $\bullet *$ & $\bullet *$ & $\bullet+$ & $\bullet+$ & + \\
3 & $\bullet *$ & $\bullet *$ & $\bullet *$ & $\bullet+$ & + & $\sqrt{ }$ & $\sqrt{ }$ \\
4 & $\bullet *$ & $\bullet *$ & $\bullet+$ & + & $\sqrt{ }$ & $\sqrt{ }$ & $\sqrt{ }$ \\
5 & $\bullet$ & $\bullet$ & $\bullet *$ & $\bullet+$ & $\bullet+$ & $\sqrt{ }$ & $\sqrt{ }$
\end{tabular}

Keterangan :

$\begin{array}{ll}\text { - } & \text { : eritema } \\ * & \text { : pembengkakan } \\ \text { - } & \text { : Infeksi sekunder } \\ + & : \text { luka mulai menutup } \\ \sqrt{ } & \text { : luka menutup }\end{array}$

Penutupan luka mulai hari ke-7, proses-proses penyembuhan luka dilihat dari eritema atau kemerahan, pembengkakan dan luka mulai menutup. Tabel diatas menunjukkan bahwa pemberian krim dari ekstrak sarang burung walet dengan dosis $10 \%$ memberikan efek penutupan luka sayat paling cepat pada hari ke-7, sedangkan paling lama penyembuhan luka sayat pada hari ke-8 dari. Dosis $20 \%$ memberikan efek penutupan luka paling cepat pada hari ke-5, sedangkan paling lama penyembuhan luka pada hari ke-8. dan pada perlakuan kontrol positif dengan povidon iodine $10 \%$ memberikan efek penutupan luka paling cepat pada hari ke-10.

Proses penyembuhan luka sayat memiliki proses dalam penyembuhannya. Ketika terjadi kerusakan mikrosirkulasi terjadi proses peradangan yang menyebabkan edema, setelah itu diikuti dengan pembentukan jaringan granulasi, proses pematangan dan remodeling dan luka sembuh.

Bahan-bahan utama sarang burung walet adalah gliko protein sedangkan komponen karbohidrat pada sarang burung walet adalah sialic acid sebesar 9\%. Komponen lainnya termasuk $\mathrm{N}$-asetilgalaktosamin (galNac) $(7,2 \%)$, N-asetilglukosamin (GlcNAc) $(5,3 \%)$, galaktosa (16,9\%) dan fucose $(0,7 \%)$. Asam amino dan garam mineral juga ditemukan di sarang burung walet, terutama natrium dan kalsium, dengan rendahnya tingkat magnesium, seng dan besi. Menurut Kathan \& Weeks pada tahun 1969 yang dikutip oleh Abidin dkk pada tahun 2011, telah menemukan tiga asam amino nonesensial (asam aspartat, asam glutamat dan prolin) dan dua asam amino esensial (treonin dan valin) pada sarang burung walet. Mereka memainkan peran penting dalam memfasilitasi fungsi tubuh normal. Dan senyawa penting diatas berperan penting dalam penyembuhan luka.

Parameter pertama pada penelitian ini yaitu dengan melihat adanya eritema, pembengkakan dan luka menutup. Kemerahan (eritema) merupakan hal pertama yang terlihat di daerah yang mengalami peradangan. Pada saat reaksi peradangan timbul, terjadi pelebaran arteriola yang mensuplai darah ke daerah peradangan. Sehingga lebih banyak darah mengalir ke mikrosirkulasi lokal, dan kapiler merenggang dengan cepat terisi penuh dengan darah. Keadaan ini disebut juga hiperemia atau kongesti, penyebab warna merah lokal karena peradangan akut. Menurut Argamula (2008), warna merah pada luka tikus merupakan hasil dari suatu peradangan terhadap luka. Reaksi ini berupa vasokonstriksi dari pembuluh darah yang segera diikuti oleh vasodilatasi. Adanya gumpalan darah merupakan reaksi platelet yang teraktivasi dan protein fibrinogen yang banyak dikeluarkan oleh pembuluh darah. Platelet akan teraktivasi untuk membentuk benang-benang fibrin yang akan menghentikan hemoraghi dan akan terlihat berupa gumpalan darah.

Berdasarkan hasil pengamatan peneliti selama penelitian, dari 15 ekor mencit yang terbagi menjadi 3 kelompok (1 kelompok kontrol dan 2 kelompok intervensi) Penutupan luka mulai hari ke-7, proses-proses penyembuhan luka dilihat dari eritema atau kemerahan, pembengkakan dan luka mulai menutup. Tabel diatas menunjukkan bahwa pemberian krim dari ekstrak sarang burung walet dengan dosis $10 \%$ memberikan efek penutupan luka sayat paling cepat pada hari ke-7, sedangkan paling lama penyembuhan luka sayat pada hari ke-8 dari. Dosis $20 \%$ memberikan efek penutupan luka paling cepat pada hari ke-5, sedangkan paling lama penyembuhan luka pada hari ke-8. dan pada perlakuan kontrol positif dengan povidon iodine $10 \%$ memberikan 
efek penutupan luka paling cepat pada hari ke-10. Suprapto (2012) menyebutkan bahwa senyawa tannin yang mampu menghambat hipersekresi cairan mukosa dan menetralisir protein inflamasi. Tannin memiliki afinitas terhadap protein sehingga dapat terkonsentrasi pada area luka

Pembengkakan terjadi pada hari ke-1 sampai ke-4, dimana luka sayat masih mengalami eritema. Menurut Luviana (2009), pembengkakan disebabkan hiperemi dan sebagaian besar ditimbulkan oleh pengiriman cairan dan sel-sel dari sirkulasi darah ke jaringan-jaringan interstitial.

Berdasarkan hasil penelitian ini, pemberian krim ekstrak sarang burung walet yang diberi perlakuan $3 x$ sehari dengan konsentrasi dosis krim 10\% dan 20\% dan providone iodine $10 \%$ sebagai kontrol positif. Hasil penelitian ini emenunjukkan bahwa dengan dosis $20 \%$ krim ekstrak sarang burung walet mampu mempercepat proses penyembuhan luka sayat pada mencit. Hal ini dikarenakan Bahan-bahan utama yang terkandung pada sarang burung walet adalah gliko protein sedangkan komponen karbohidrat pada sarang burung walet adalah sialic acid sebesar 9\%. Komponen lainnya termasuk N-asetilgalaktosamin (galNac) (7,2\%), Nasetilglukosamin (GlcNAc) (5,3\%), galaktosa (16,9\%) dan fucose $(0,7 \%)$. Asam amino dan garam mineral juga ditemukan di sarang burung walet, terutama natrium dan kalsium, dengan rendahnya tingkat magnesium, seng dan besi. Menurut Kathan \& Weeks pada tahun 1969 yang dikutip oleh Abidin dkk pada tahun 2011, telah menemukan tiga asam amino nonesensial (asam aspartat, asam glutamat dan prolin) dan dua asam amino esensial (treonin dan valin) pada sarang burung walet. Mereka memainkan peran penting dalam memfasilitasi fungsi tubuh normal. Dan senyawa penting diatas berperan penting dalam proses penyembuhan luka.

Pada kelompok sarang burung walet $20 \%$ terbukti lama proses penyembuhan lebih cepat dibandingkan dengan kelompok sarang burung walet $10 \%$ dan kelompok kontrol iodine $10 \%$. Perawatan luka sayat punggung yang dilakukan peneliti pada tikus rattus norvegicus dilakukan sebanyak 3 kali sehari tiap 8 jam. Hasil penelitian ini sesuai dengan penjelasan Syamsuhidajat pada tahun 2010, perawatan luka tergantung pada jenis luka, ada tidaknya resiko perdarahan yang dapat menimbulkan infeksi oleh karena terdapat manajemen luka yang pertama adalah mengontrol inflamasi, mengurangi jumlah perkembang biakan kuman, mencegah infeksi dan mengatasi infeksi, kedua mempertahankan kelembaban yang seimbang, melindungi kulit dari trauma, melindungi kulit sekitar luka, tepi luka diperhatikan agar proses epitelisasi berjalan dengan baik.

\section{Tabel 2 Waktu Penyembuhan Luka Mencit dengan uji Anova}

\begin{tabular}{|c|c|c|c|c|}
\hline $\begin{array}{c}\text { Waktu } \\
\text { sembuh } \\
\text { luka }\end{array}$ & N & SD & mean & sig \\
\cline { 1 - 4 } Sbw 10\% & 5 & 0.000 & 13.000 & \multirow{2}{*}{0,001} \\
Sbw 20\% & 5 & 0.548 & 2.60 & \\
\hline Iodine & 5 & 0.548 & 1.60 & \\
\cline { 1 - 4 } Total & 15 & 0.737 & 2.40 & \\
\hline
\end{tabular}

Dari tabel diatas diperoleh nilai $\mathrm{P}(\mathrm{P}$-value $)=0,001$. Dengan demikian pada taraf nyata $=0,05$ yang berarti menolak Ho, sehingga kesimpulan yang didapatkan adalah ada perbedaan yang bermakna waktu penyembuhan luka pada ketiga kelompok perlakuan tersebut

Menurut penelitian Falanga pada tahun 2007, pada manusia dan golongan vertebrata yang lebih tinggi penyembuhan luka terjadi melalui suatu proses perbaikan dimana hasil yang dicapai bukan berupa restorasi secara anatomi namun lebih kepada hasil yang fungsional. Hasil dari mekanisme penyembuhan luka ini tergantung dari perluasan dan kedalaman luka, panjangnya luka serta ada tidaknya komplikasi yang mengganggu perjalanan proses penyembuhan luka yang alami.

Proses penyembuhan luka melalui empat tahap yaitu tahap respon inflamasi akut terhadap cidera, tahap ini dimulai saat terjadi luka, pada tahap ini terjadi proses hemostatis yang ditandai dengan pelepasan histamin dan mediator lain lebih dari sel-sel yang rusak disertai dengan proses peradangan dan migrasi sel darah putih ke daerah yang rusak. Selanjutnya adalah tahap destruktif yaitu terjadi pembersihan jaringan yang mati oleh leucocyt polimorfonuclear dan makrofag, tahap proliferatif merupakan proses yang terjadi karena pembuluh darah baru diperkuat oleh jaringan ikat dan menginfiltrasi luka, dan akhirnya tahap maturasi terjadi reepitelisasi, kontraksi luka, dan organisasi jaringan ikat. 


\section{Kesimpulan}

Pemberian krim ekstrak sarang burung walet dengan dosis $10 \%$ memberikan efek penutupan luka sayat paling cepat pada hari ke 7 sedangkan pada pemberian dosis $20 \%$ memberikan efek penutupan luka paling cepat pada hari ke 5. Dan berdasarkan hasil uji analisis didapatkan keseimpulan bahwa pemberian krim ekstrak sarang burung walet efektif terhadap percepatan penyembuhan luka sayat pada hewan uji mencit.

\section{Daftar Pustaka}

Abidin, F.Z., Hui, C. K., Luan, N. S., Ramli, E. S. M., Hun, L. T. and Ghafar, N. 2011. A. Efects of edible bird's nest (EBN) on cultured rabbit corneal keratocytes. Available from://www.biomedcentral.com/1472-6882/11/94

Juwita Nanda. 2011. Faktor-Faktor Yang Mempengaruhi Kesembuhan Luka. [skripsi]. Fakultas Kedokteran Universitas Brawijaya.

Jain, S. 2012. Dermatology. Journal of Ilustrated Study Guide and Comprehensive Board Review. USA: Springer Science, Bussiness Media. ILC. p. 2-10. Kaminer, M.S. Photodamage: Magnitude of the Problem. in: Gilchrest, B.A., editor. Photodamage. Blackwell Science; p.3-9.

Kozier. 2010. Buku Ajar Fundamental Keperawatan: Konsep, Proses dan Praktik. Jakarta: EGC.

Manjas, M., Henky, J. and Salmiah, A. 2010. Penggunaan Krim Amnion pada Penyembuhan Luka Sayatan Tikus Wistar. Majalah Kedokteran Indonesia,Volume 60, Nomor: 6, Juni 2010

Nakagawa, H., Hama, Y., Sumi, T., Li, S., Maskos, K., Kalayanamitra, K.,Mizumoto, S., Sugahara, K. And Li, Y. 2007. Occurrence of a nonsulfated chondroitin proteoglycan in the dried saliva of Collocalia swiftlets (edible bird's-nest). Glycobiology. 2007; vol. 17 no. 2 pp. 157-164.

Notoadmodjo, S. 2012. Metodologi Penelitian Kesehatan. Jakarta.PT: Renika Cipta.

Rohmah,S. D. 2013. Formulasi krim sarang burung walet putih (aerodamus fuciphagus) dengan basis type a/m sebagai pencerah kulit wajah. Pontianak: Universitas Tanjungpura.

P. Driscoll. 2013. Incident Of Surgical. Medmarket Diligence. Worldwide Wound Management.

Prasetyo BF, Wientarsih I, Priosoeryanto BP. 2010. Aktivitas Sediaan Gel Ekstrak Batang Pohon Pisang Ambon Dalam Proses Penyembuhan Luka Pada Mencit. Jurnal Veteriner 2010; 11 (2): 70-73

Suprapto AK. 2012. Efek Salep Ekstrak Metanoldan Salep Serbuk Daun Sosor Bebek (Kalanchoe pinnata (Lamk)) Terhadap Penyembuhan Luka Sayat Pada Mencit (Karya Tulis Ilmiah). Bandung: Fakultas Kedokteran Universitas Kristen Maranatha.

Suryadi. 2011. Perawatan Luka jilid 1. Jakarta Sayung Seto. Hal: 7-11, 13-16, 79,81.

Swarjana IK. 2012. Metodologi Penelitian Kesehatan. Yogyakarta: Penerbit Andi.

Triani. 2011. Proses Pemutihan Sarang Burung Walet Hitam (C. maxima) dengan Menggunakan Hidrogen Peroksida (H2O2). [skripsi]. Fakultas Pertanian Jurusan Peternakan. Universitas Bengkulu.

Wheindrata, HS. Sp.W. 2015. Beternak Burung Walet dan Burung Seriti satu atap. Yogyakarta: Lili Publisher

WHO. 2014. World Health Statistic: World Health Organisazion 